\title{
The Emperor's New Makeup: Cool Cynicism and Popular Music Criticism
}

\author{
John M. Sloop
}

In 1991, in a now oft-quoted observation, Andrew Goodwin notes an interesting development in the relationship between the academy and popular culture: "Abstruse French theory has 'trickled down' into the popular consciousness, ..... so that the word 'postmodern' reached record stores, magazines and television programmes just a few years after it entered the academy" ("Popular" 186). ${ }^{1}$ This proliferation of the term "postmodernism" and its associated themes in mass media outlets has become the concern of some academic popular music critics because, they argue, such commentary misreads the political commitments of music fans and youth culture. For example, elsewhere, Goodwin (Dancing) argues that (academic) "postmodern"2 theories that posit a depletion of political meaning in music fanship and music video misrepresent the ways in which viewers and listeners actually consume both music and music video, as well as the ways videos are structured. Indeed, for Goodwin, many of the examples others employ of "postmodern texts" appear to him to work under paradigms of modernism, such as authorship and authenticity (Dancing 15-22, 72-74). More recently, Neil Nehring has traced out theoretical sympathies between such academic theorists as Lawrence Grossberg and Steve Redhead and popular music critics such as Simon Reynolds and Tom Frank, suggesting that popular criticism reflects the tenor of academic criticism. More, he notes that these arguments-concerning the growth of a cynical form of fanship that takes popular music to be void of political meaning-disregard the sincere political readings and emotions of contemporary popular music fans. ${ }^{3}$

While it is no doubt valuable to investigate the changing notion of "authenticity" and the politic commitments of fans in general, the multiple genres of popular music and demographics of fanship are obviously too complicated to allow broad claims to be of much value. ${ }^{4}$ Indeed, it is more likely the case that each individual fluctuates in his or her political commitments and musical attachments based on a large number of factors, including the musical genre, the specific artist, the community of 
other fans, and the overall cultural condition. Nonetheless, the relationship between popular music criticism, popular music fanship, and cultural politics is a vital one, especially if music criticism is creating an interpretive frame for fanship relatively void of politics. As a result, I would suggest that the question of the relationship between criticism and "postmodernity" as an aesthetic be investigated on the level of individual case studies. Rather than attempt to provide an exploration of youth culture, authenticity, and the question of "postmodernity" in total, then, I will investigate a specific case involving relationships between popular criticism, fanship, and postmodern aesthetics. ${ }^{5}$ Through a reading of mass-mediated criticism (and coverage in general) of rock bands Kiss and the Sex Pistols during the late 1970s and during their reunion tours in the late 1990s, I will suggest that, in these cases at least, "post" themes have indeed become a common (and troubling) element of popular criticism. After noting the different notions of authenticity and the different criteria of judgment employed in music criticism at each end of this two-decade gap, I will discuss the problematic implications of contemporary criticism and our (i.e., academic critics) role within it.

In short, the emergence of "post" theses in popular criticism is important if Simon Frith is correct in noting that, in the end, rock criticism isn't concerned with representing music to the public but with "creating a knowing community" (67). That is, like all public discourse, rock criticism rhetorically constitutes an audience that agrees to its meanings. Rock criticism that posits "post" assumptions about music and music fanship helps create audiences who can consume with those assumptions as their interpretive frame. Hence, rather than arguing over whether contemporary popular music is modern or postmodern or whether mass culture in general has developed a general postmodern aesthetic, I want to use these cases as suggestions of the problematic ways popular music criticism encourages an aesthetic that is celebratory toward cynical selfreflectiveness and musical commodification. ${ }^{6}$

The Changing Face of Authenticity: Kiss and the Sex Pistols

April 6, 1997: I'm sitting in my chair in the front row of the first tier of balconies in the Nashville Arena, surveying the audience and simultaneously being fooled time and time again by members of the audience dressed up as one of the four members of Kiss. ${ }^{7}$ As anticipation grows, the Who's "Won't Get Fooled Again" roars through the arena's speakers. Just at the moment when Roger Daltrey cynically hails the new boss ("same as the old boss"), the sound engineer turns up the volume, a Kiss banner unfolds behind the stage, and the lights go down as the crowd roars its approval. When the first notes of "Strutter" begin, I real- 
ize that rather than reading the Who's song as I normally do-as a stark commentary on the corrupting influence of power-Kiss's use of the song on this tour provides a very different frame for deciphering the lyrics. Rather than criticism, the lyrics unite the crowd in a celebration of Kiss's return to the center of box office supremacy. The new boss, same as the old boss.

As the concert proceeds, lead singer Paul Stanley, amidst all of the normal pandering of large arena concerts (e.g., "We love you, Nashville"), persistently refers to the triumph of Kiss's return as evidenced by box office figures. After announcing that the arena was witnessing its largest ever audience, Stanley commented, again to thunderous cheers: "Everyone in this audience tonight should be proud of themselves. Because of you, we are again the number one grossing band in America." The constant reminders that Kiss was the "biggest moneymaker this year," and that the audience should take pride in making this so, only seemed to bring more applause.

While I tried to remain somewhat detached from the show, to be an observer of popular culture and consumption in what seemed to be a fairly unique setting, I became more physically involved in the show than I expected. While I felt like sleeping through a forgettable opening act, the buzz of the Kiss show put my body into celebratory overdrive. In listening to the note-by-note replication of their 1977 tour, I, along with the entire auditorium, celebrated each familiar song, each remembered instrument solo.

In 1977, Gene Simmons seemed to be making the turn toward a celebratory theory of pleasure years before some cultural critics, when he noted in the New York Post that the band forced fans "to jump past the thinking process because that's the thing that restrains people from having a good time. Our concerts don't mean anything-they are an experience in letting your guts out" (quoted in Lendt 26). However, given that throughout the ' $70 \mathrm{~s}$, employing a romantic notion of musical authenticity and meaning, I had been offended by Kiss's music to the degree that I thought it was oriented more toward sales than "art" or politics, why did I enjoy this show so much now? And given that the overall sexism of their lyrics and style had always been offensive to me, how was I taking such pleasure in this show? The reasons are multiple and complicated, of course, and in the end, all of them aren't relevant to my story. How I justified my pleasure later, however, and how popular music criticism ${ }^{8}$ helped me do so, is important. As I discussed the show with friends and colleagues later, I turned the campy replication into a fairly theoretically sophisticated event - the show became an example of a Baudrillardian simulation, a self-reflective carnival; the band's con- 
stant references to how big the event was, how much money they were making, became a carnivalesque celebration of excess, a postmodern self-referential nod in which audience and band were in on this hugely elaborate joke together. Even the sexism of their lyrics didn't matter when we knew it was all façade. Unlike the 1970 s, this time we were all aware that it was a joke, Kiss knew we knew, and most of the fun was in playing along like no one knew.

In the next few months, I purchased several Kiss CDs that had come out in the years between their '70s heyday and their reunion tour. A few months later, as I was leaving Media Play with a box set of Kiss action figures ("collectors' items," I thought to myself), I found myself frozen by my actions. Cynical or not, in on the joke or not, I was walking through the act of consumption, finding a way to value Kiss and what it had to say, by intellectualizing the joke itself. In part, I was able to muster this reading of Kiss (with a good deal of company) because popular music criticism about Kiss and other reunion tours in 1996 echoed some of the same arguments and themes being made in academic criticism concerning "postmodernity."

To understand some of the changes that have occurred in criticism of popular music (or at least this segment of it) over the last two decades, especially changes in the rhetoric of authenticity and commodification, I will turn first to a reading of mass media news articles and critical reviews of both Kiss and the Sex Pistols from 1977 and, second, I will discuss the reviews of each band's reunion tour in 1996.9 Rather than investigate fanzines about either band, I have chosen for the most part to investigate national music and news publications (see footnotes 9 and 10 for a discussion of source selection). I do so in order to understand the thematic discourses that surround the bands (and music consumption) on a dominant level. While it is certainly the case that some fans will transform or undermine critical interpretations, the discourse investigated here provides a strong sense of the dominant tropes of rock criticism that operate in either period. ${ }^{10}$

While I'm more interested in the discourse surrounding Kiss, especially in 1996, a brief comparison/contrast with the discourse surrounding the Sex Pistols is particularly instructive in that these two bands represented for critics two different sides of the "authenticity" coin in the late 1970s and, later, in 1996. In two different investigations of the dominant themes of rock music criticism/writing, Steve Jones ("ReViewing" and "Covering") argues that two of the dominant themes in discussions of rock music are authenticity and commercialization (i.e., is the band producing the music "just for the money"). These two concepts are tightly connected, of course, and are the primary ways in which Kiss 
and the Sex Pistols are discussed (and sometimes compared). Popular memory would have it that the Sex Pistols met with great critical appraisal in terms of rock's traditional ideology of "authenticity." The notion of authenticity in rock culture has traditionally signified, as Grossberg (202) suggests, that the music is meaningful, unique, and politically uncompromised. On the other hand, Kiss would be expected to be situated as "inauthentic"-commercially and politically co-opted, superficial, and manufactured (Grossberg 202).

A quick look at any of a number of sources reveals such a division between Kiss and the Sex Pistols in terms of early critical reception. If we look at rock music criticism in the New York Times, for example, we find numerous ways in which critic John Rockwell plays into the ideology of rock "authenticity." Of the Sex Pistols, Rockwell notes, "The music will naturally not be to everyone's taste-it's too brutally uncompromising for that ... " "The Sex" 16). The Sex Pistols are described as having a "philosophy" which articulates the group's generational "hatred of phoniness" ("The Sex" 16); their songs "have a strength and an individuality both in the words and in the music that sets them above nearly every other . . . punk band ..." ("The Sex" 68). In a Billboard essay reporting on A \& M Records' London office signing of the Sex Pistols, A \& M Managing Director Derek Green observes that the Sex Pistols were signed because of their status as an important "new force" in music with a "point of view about the "establishment," a band which radio people "believe in" (White 70). After being dropped from A \& $M$ (their second label) and signed to Virgin Records, Billboard's report noted the multiple ways in which the group is important as a historical force that has disrupted the rock industry; the Sex Pistols are given credit for allowing many new bands to emerge in their wake (P. Jones 68). Further, Virgin's Richard Branson claims that signing the band seemed especially fit for a "truly independent" company ( $\mathrm{P}$. Jones 68 ). ${ }^{13}$ In other essays, the band is cited as critically being "generally accepted as the leaders of Britain's punk rockers" (Rockwell "Sex" 4). In Charles Young's (1987)"14 coverage of the Sex Pistols in Rolling Stone, he celebrates their noncelebrity attitude, making it clear that while other bands might be in the business for celebrity or fame alone, the Sex Pistols took "the road less traveled" (318). Finally, punk itself, and especially the Sex Pistols, is described in pseudoacademic language as a "socio-musical phenomenon" with "political content" (Reed 2). The terms used in articulating the Sex Pistols-individual, uncompromised, political, anti-phony and hence authentic-are all key descriptors in the articulation of traditional "authenticity" in rock culture.

The 1977 reviews of Kiss, on the other hand, articulate them as the political and artistic inverse of the Sex Pistols-critical failures, utterly 
compromised, apolitical, and shallow. For example, in reviewing their show at Madison Square Garden, John Rockwell argues that Kiss "is a big, blowzy, amiable cartoon, a sort of animated version of comic-book superheroes. .. ," "this year's Alice Cooper" ("Kiss" 12). Their act is "a pretty shallow show, and surely their fans will catch on to that shallowness soon" ("Kiss" 12). Colette Dowling offers to explain the Kiss phenomenon to baffled parents in a lengthy essay, and Kiss is again referred to as a group of comic book heroes, a neo-Alice Cooper act (18-19). Further, Dowling consistently makes reference, in derisive fashion, to Kiss as a marketed entity. Hence, in a clear stress of inauthenticity, she notes that "there are at least a dozen companies involved in the making of Kiss" (68, emphasis mine). The essay examines the marketing and merchandising of Kiss, and includes the story of a 32-year-old former actor who is said to have taught the band how to dance, to make their show "look big" (69). Metaphorically and descriptively, Dowling situates Kiss as manufactured product rather than artistic expression. After quoting John Rockwell directly comparing Kiss fans unfavorably to the punk subculture (i.e., Kiss fans "don't want real anarchy, they want the illusion of anarchy"), Dowling concludes that a Kiss concert "has everything to do with making money and nothing at all to do with making music" (69). Finally, trade publication Billboard covered Kiss three times in 1977, once to note that a Gallup Poll found Kiss to be the favorite band of teenagers ("Poll" 89) and twice to review live shows. In the reviews of concerts at The Forum in Los Angeles and Madison Square Garden in New York, Claude Hall notes of the former that the fans were there more for Kiss's stage effects than for their "middlingly decent" music (37), while Dick Nusser notes of the latter show that the excitement of the audience "seems to have more to do with Kiss' style than the group's musical expertise" (89). Again, what we see, especially in comparison with the discourse surrounding the Sex Pistols, is an inverted image in which Kiss represents inauthenticity in the terms of rock ideology - the pursuit of money rather than art or politics, commercial compromise, illusion rather than reality. In 1977, then, each band was critically understood through fairly clearly defined categories that outlined the values of rock culture. Further, in keeping with the ideology of rock authenticity, the band with the greatest success in terms of financial capital met with a deficit in terms of critical cultural capital.

In his overview of contemporary popular music theory, Keith Negus notes that multiple historians and theorists of popular music tell a story in which the origins of rock and roll are found in the mid 1950s and its conclusion in the 1970s with the advent of punk (136). While Negus disagrees with the way that history is told, he acknowledges that 
such a narrative has its effects on the ways the "authenticity" of music is discussed now. Indeed, Negus's concern, like that of Nehring and Goodwin, is that such a story wrongly argues that contemporary popular music fanship has been reduced to instances of Grossberg's oft-noted concept of "authentic inauthenticity"-a situation in which fans consume music on radically contingent grounds, in which there is indifference to difference. When musical politics and consumption are filtered through an ideology of authentic inauthenticity, differences between the purpose and function of various bands and genres are not denied, but they are assumed to be so relative as to be beyond investment for fans (Grossberg 225). In short, such theorists are arguing that we have entered a cultural condition in which authenticity and inauthenticity have largely lost their moorings as guiding concepts for youth culture. While Grossberg is often misread as if he were claiming that all fanship is currently invested in "authentic inauthenticity," it is difficult to deny that something of the rhetoric "about" contemporary music popular does reflect some form of this authentic inauthenticity. ${ }^{15}$ Assuming that this attitude about music has taken hold to some degree in music criticism, the question I am posing here is, what kind of an audience does. such an orientation, an orientation that collapses the distinctions between authenticity and inauthenticity, constitute for the consumption of popular music? While as a cultural critic I take the distinction between "authenticity" and "inauthenticity" itself to be a rhetorical one, there are "real" political differences in the meaning of music depending on whether or not the distinction is employed in the consumption of music. Hence, if punk is represented as the last gasp of rock and roll, and yet rock still goes on in an "authentic inauthentic" way, how is popular music discussed critically and what are the potential effects of such talk on its consumption?

Historical circumstances treat us well in this investigation as both Kiss and the Sex Pistols launched reunion tours at roughly the same time in 1996. This time, the discourse surrounding the bands had to grapple with the current state of rock culture as well as with the past articulations of the two bands. While the two are often talked about and compared directly in discussions of reunion tours, ${ }^{16}$ and this itself shows something of their emblematic nature as bands representing "authenticity" and "inauthenticity" in rock's past, I want to deal with each separately here, again, placing my primary attention on Kiss given the importance of understanding the popularity of a band received as "inauthentic" in traditional terms. Further, while I grant that there is a distinction to be made between reunion tours of bands that were at peak visibility two decades ago and bands that are releasing their first recordings in the 1990s, the 
case is instructive in illustrating the terms currently being used in the popular lexicon to discuss popular music.

In putting together their reunion tour, the Sex Pistols put a cynical spin on the reasons for the tour when lead singer John Lydon (Johnny Rotten) answered the "Why?" question with a brief, "Your money" (Jenkins G2). Named the "Filthy Lucre" tour, such cynicism about the purposes of the tour and its meaning are discussed by critics as if the band had caused a breech of authenticity (and a breech in some unspoken commitment between critics and the band during the 1970s). Indeed, Rolling Stone author David Wild, noting how the tour undermined rock authenticity for the Sex Pistols, observed: "1996 looks to be the pretty vacant summer when we lose our remaining punk innocence and confront the fact that maybe there wasn't all that much difference between the Sex Pistols and Kiss after all" ("Tours" 52). While providing a positive review of the Sex Pistols' first show on the reunion tour, Robert Christgau of the Village Voice also notes the ironic nature of the tour itself: while a Kiss reunion is sensible because Kiss is "crass by definition, ... punk nostalgia, on the other hand, is a grotesque oxymoron" (48). Similarly, David Sinclair's review of the same show for Rolling Stone noted that the technical performance of the songs was pleasant but that the show was seen "as the least welcome rock \& roll comeback of all time, a crass betrayal of the original do-or-die punk philosophy" (30), again making clear that the Pistols had "made no bones about their enthusiasm for converting their mythical status into hard cash" (30). Finally, Richard Harrington's Washington Post review of the show at Fairfax, Virginia's Patriot Center was titled "Apathy in the U.S.A." and reflects that while one could imagine that the Sex Pistols were perhaps "dangerous" in the past, lead singer Johnny Rotten replaced "punk's anarchic edge with British music-hall burlesque" (C2). In each case, critics discuss the specific concert and the reunion in general in such a way that the Sex Pistols tour betrays punk authenticity in favor of the inauthenticity of performance for cash. As such, the reviews are often positive about the technical matter of performance while simultaneously observing the breakdown of authenticity. At the very least, the discourse of these reviews illustrates the existence of some concern with past notions of authenticity, at least among rock reviewers, while simultaneously indicating that these same critics now find the concept to be an empty one-authenticity was part of the tenor of cultural innocence, and the reunion is the final sign of its death.

Kiss, however, presents something of a different equation. Given that "Kiss is crass by definition" (Christgau 47), we are faced with a different rhetorical situation and articulation for their reunion tour. While 
the authenticity of the Sex Pistols (and authenticity in general) is rhetorically undermined by their reunion, what happens when a band widely seen as "middling," based in style over substance, derided as a money machine, reunites for a tour twenty years after the fact, especially in an era when the notions inspired by "post" theories have trickled into popular music criticism? In a 1976 letter to the New York Times, Jeff Robbins noted that Kiss's fans seemed to need a high-level dosage of stimulation to get "turned on," and he wondered what the band would have to do in the future to maintain their popularity when the novelty wore off: "What will Kiss 2001 have to do to turn them on?" (46). The answer, it appears, is nothing new, and perhaps they need do nothing new because the discourse surrounding rock, or at least the value of "authenticity" as a guiding concept, has changed. If there is not a difference between Kiss and the Sex Pistols after all, as we learn from one of the reviews of the Sex Pistols reunion, then both bands were always "about" commodification and sales (rather than originality and authenticity). Indeed, it is this acceptance of the commodification of rock and the acknowledgment of a lack of authenticity that pervade reviews of the Kiss's reunion tour. If anything, Kiss is celebrated for their commodification because they, unlike the Sex Pistols, never pretended to be "about" anything else. To borrow from Grossberg again, in this case, Kiss is positioned as worthy of ironic praise because they were always aware of their own authentic inauthenticity (even if their fans were not).

When Kiss unmasked in the early ' 80 s, it was to a fan base that was fairly indifferent, perhaps slightly perturbed at having been fooled by the band's carnivalesque atmosphere to begin with. So now, why (and in what ways) was the band being celebrated in 1996 and 1997 for putting the makeup on once again? And what are the political implications of this praise? The reviews of their reunion tour take on two major forms: first, a celebration of the sales generated by the tour and its merchandising (and generating other reunions) and, secondly, a celebration of everyone being in on the irony of the reunion as a reproduction of something always already "inauthentic."

In the first of these threads, we see rock magazine publications that were critical of Kiss during their 1970s heyday, such as Rolling Stone, now celebrating Kiss for such economic moves as encouraging the MUZAK corporation to record four of their songs and for putting out a line of Kiss character credit cards (Bozza 24); Kiss is credited with helping bring on the flurry of revenue-producing reunion tours (Ali 44); David Wild notes that while "former critical darlings the Sex Pistols were selling out artistically, Kiss are kicking box office ass" ("Performance" 32). Forbes magazine published an article focusing on the major 
business of reunion tours and placed a good deal of their focus on Kiss, beginning the article with the story of a fan who spent $\$ 225$ on tickets to a Kiss show and $\$ 315$ for merchandise. While Forbes notes that the show is more about the show than the music, it is also noted that Kiss's bottom line will place them at number 29 on Forbes's Top 40 (LaFranco 157).

In the second set of observations about Kiss, there is a celebration of irony (and the implied celebration of commodification), and it is in this turn that we most clearly see examples of the discourse of authentic inauthenticity. While no one writes about "postmodernism" or "poststructuralism" by name, and while no one celebrates the death of "authenticity," these reviews celebrate Kiss for their merchandising potential while simultaneously noting that the band doesn't have much to offer in terms of sincerity, originality, or truth. Again, in addition to Robert Christgau's (1996) comments, Brett Milano notes this lack of originality (authenticity) in Stereo Review by observing that a good number of reviewers "hated Kiss in the Seventies because they were really dumb and all their songs sounded the same" (82). However, he adds, "with the revival of every self important Seventies band, . . . we're starting to realize why we should have liked Kiss all along: because they're really dumb and all their songs sound the same" (82). In such a move, bands that were important to critics and fans in the 1970s based on claims of integrity and originality are now posited quite clearly as only "self-important." More, such essays are implying that what should be celebrated in rock culture is the open honesty of monotony and repetition-the very antithesis of romantic authenticity. David Wild observes, "Sure Kiss sucks, but give them a little credit; they've sucked for more than 20 years now," again, celebrating something which should have been antithetical to rock authenticity ("Performance" 32). Finally, the most interesting comment on the Kiss reunion tour, the one that most clearly exemplifies the articulation and celebration of Kiss as authentically inauthentic, is offered by R. J. Smith in a cover article in Spin: "KISS went out as cheese," Smith observes, "and they have come back as, well ... fromage" (40).

When Kiss left the forefront in the late '70s/early ' 80 s, they were American cheese that was no longer wanted, no longer of cultural value. American cheese is not meant to be a vital food source; it is something that looks and feels like real cheese but at best simulates its look and texture. While such a simulation couldn't meet critical approval in a popular critical culture in which authenticity signified depth and originality, the critical climate has changed. Kiss returns with the exact same act, the exact same sequence of songs, the same texture and smell, but they are 
now fromage, a version of cheese with higher cultural capital. It is a cheese, fittingly, with a French accent, the same accent that is credited often, rightly or wrongly, with the emergence of poststurctural theories and a postmodern aesthetic. While such a reading is clearly a conflation and confusion of a great deal of theoretical work, there is certainly a cultural sense of a "postmodem aesthetic" being equated with self-reflexive, in-on-the-joke, thinly layered, cynicism. ${ }^{17}$ While I'm not interested in arguing over the "real" existence of such a condition, there are cultural implications to be thought through when critics promote and celebrate this aesthetic, and it is to this, and what we might do about it, that I turn next.

\section{The Emperor's Makup}

In a charming and telling passage of Slavoj Zizek's For They Know Not What They Do, we are returned to Hans Christian Andersen's story of the child who points and declares "The Emperor has no clothes." Zizek notes that the story of this child with such disarming innocence is generally employed as an example of the way in which the obvious can deliver us from stuffy hypocrisy. However, Zizek warns us that there is a danger in pointing out the emperor's nakedness (For 11). While we may intend to only be rid of unnecessary hypocrisy and pretense, after the Emperor is disrobed, "When it is already too late, we suddenly notice that we got more than we bargained for-that the very community of which we were a member has disintegrated" (For 11). Zizek's point is that there are times at which it may be best to play along with the façade of "invisible clothes," of playing as if contingent morals, contingent order, are indeed the real thing. If the community constituted by the rhetorical illusion of the clothes is better than other potential communities, why force everyone else to see the illusion? For example, if pointing out that the Emperor's democratic clothes are not real would give way to fascistic nationalism, perhaps we should let the Emperor keep his clothes.

While I'm obviously dealing with something of a smaller nature here, I am concerned with what it means to point out the "nakedness" of authenticity and to then celebrate this nakedness. What does it mean to celebrate the "dumbness" of Kiss or of commodification laid bare? To play with Zizek just a bit, perhaps the question I'm posing is this: "What happens when we give the Emperor his clothes back?" or better, with Kiss as naked emperor, "What happens when we give Kiss back their makeup?" Giving the Emperor's clothes back is quite a different matter than never having removed them at all. Once the child tells us that the Emperor has no clothes, it's much more difficult for the Emperor to put 
them back on, for us to ever believe again. At the very least, for the Emperor to put the clothes back on and parade in front of the kingdom takes a great deal of purposeful delusion on all our parts. In giving the clothes back, our only option is to know that we are remembering the outfit. The naked emperor walks down our streets, showing off his new threads, and we cheer enthusiastically about their beauty. Our community is held together only by each of us suspending our awareness of nakedness during formal events, even if we are always aware that the clothing is an illusion. Similarly, the rhetoric of "post" popular music criticism, stripping off layers of "authenticity," celebrating Kiss's nakedness, encourages a "postmodern" aesthetic of popular music fanship as much as it reflects it. With "authenticity" stripped bare as a functional concept, we are positioned to laugh with the Emperor about the illusion we shared in the past while we continue to act is if we share it now. ${ }^{18}$

In her review of Quentin Tarantino's Pulp Fiction, bell hooks notes that Tarantino's vision is one of "white cool: a hard cool cynical vision" (47-48). hooks claims that the "fun" of Tarantino's films "is that he makes that shit [sexism, racism, oppression] look so ridiculous you think everybody's gonna get it and see how absurd it all is. . . . Well, that's when we enter the danger zone. Folks be laughing at the absurdity and clinging to it nevertheless" (47). ${ }^{19}$ When Kiss puts their makeup back on, we are all in on the joke. We enjoy the show and in some sense value its celebration of capital and sexism precisely because it seems to let us know that they don't "mean" it and that it doesn't matter. Dressed in a French style, the King's nakedness isn't all that bad-indeed, there is something slightly charming about it. Kiss as fromage rather than American cheese encourages audience members to find problematic (e.g., sexist) lyrics humorous ("Oh, come on, it's only a show") and to celebrate consumption itself as if consumption (of credit cards, dolls, T-shirts, merchandising) somehow lets us in on the joke, negating its impact. We continue consuming and ignoring all because we are able to do so with a clear theoretical and cultural conscience.

One of the guiding concerns for Slovaj Zizek has been his elaboration of the concept of "enjoyment"-what people value through enjoyment, how people behave toward their objects of enjoyment, and, as in this essay, how people "enjoy" ironically and to what end. In For They Know Not What They Do, Zizek, a psychoanalytic critic, notes that psychoanalysis is a much harsher critic than Christianity: "Ignorance is not a sufficient reason for forgiveness since it conveys a hidden dimension of enjoyment. Where one doesn't (want to) know, in the blanks of one's symbolic universe, one enjoys, and there is no Father to forgive ..." (2). In essence, in distinction to celebratory configurations of enjoyment, 
Zizek points to the ways in which enjoyment "itself, which we experience as 'transgression,' is in its innermost status something imposed, ordered-when we enjoy, we never do it 'spontaneously,' we always follow a certain injunction" (For 9). More, in his earlier The Sublime Object of Ideology, Zizek notes that "Cynical distance is just one wayone of many ways-to blind ourselves to the structuring power of ideological fantasy: even if we do not take things seriously, even if we keep an ironical distance, we are still doing them" (Sublime 33). Zizek's concern, like hooks's argument with Pulp Fiction, is that in the pleasures we take, even when we think they are transgressive, and even if they are in fact transgressive in certain regards (e.g., there may be something transgressive about the reading of a lower cultural capital object in the terms of high cultural capital), there is always a particular form that is being followed while we laugh at our awareness of that form: "What is really at stake in ideology is its form, the fact that we continue to walk as straight as we can in one direction" (Sublime 33). Indeed, we can only "enjoy" cynically to the degree that we somewhat forget the very pattern that we replicate. Hence, with Kiss, we can only enjoy the transgression of simulation to the degree that we are able to disregard the way in which our self-reflective critical practice continues to value (in terms of discursive space and in terms of market value) some of the very forms we may want to criticize (e.g., sexism, capitalism, commodity fetishism). As Zizek notes, if we could truly be aware of the multiple ways in which our behavior were complicitous with existing ideology, we couldn't enjoy it because such awareness "would reveal that ideology serves only its own purposes" (Sublime 84).

\section{Pain (and Noise) as Critical/Political Impetus}

What, then, do Zizek and the above case study teach us about contemporary music criticism and its "values"? I want to use the term value here in moving toward an answer as a nod to Simon Frith's Performing Rites: On the Value of Popular Music, a book that reminds cultural critics that in addition to providing fans with rhetorical and cultural positions from which to base and reaffirm identities, music fanship and music criticism (academic and popular) are part of the process of defining cultural values and changing them.

Frith asks us to think about the potential dangers of popular criticism when it shuts down, rather than explores, productive cultural change. A fanship or critical ideology that endorses an ironic glance about the meaning of music, as we see in the case investigated here, endorses existing meanings rather than challenging them. To be transformative of existing meanings, discourse " ... must challenge experience, 
must be difficult" (20). Regardless of how much one could argue that changes in media forms make changes in aesthetics inevitable, it is also the case that, as Frith notes, popular criticism constitutes audiences, shaping identity and values. Hence, popular music criticism does its best ideological work when it challenges popular notions rather than accepting or implicitly reaffirming them. If scholarly criticism is to investigate inequities, it cannot do so by celebrating ironic cynicism; the same is true of popular music criticism.

However, Frith makes this critical task appear easier than it probably will be for many critics when he acknowledges that he "most highly" enjoys "that music, popular and serious, which has some sort of disruptive cultural effect," music that allows him to "participate in imagined forms of democracy and desires" (his examples are women's music, gay music, African American music) (274). And this is where the problem comes in for many critics. While Frith seems to already take pleasure in disruptive forms of music, I (and evidently a good number of mass media popular music critics) find myself at times valuing something that is less disruptive of contemporary culture, like Kiss, for a number of reasons (e.g., in part because I find reflective enjoyment in celebrating "low culture," in part because I find the "post" cynicism of popular criticism so enticing, so entertaining, and so affirming of the theories we read). Hopefully, like Frith, many times our politics have already conjoined with our pleasures - bodily and cerebral -in such a way that our values provide us with a utopian possibility that we are somewhat comfortable envisioning. But obviously, this is not always the case.

Hence, we have to ask, how do we approach the music we value when it contradicts our desires to transform culture, and, more, what musics do we "value" in the place of those less transformative ones? While Frith takes us a good ways toward a satisfactory political answer, given that his own tastes and his own aesthetic are less troublesome than many people's, a few additional comments are in order. We recall that Frith wants to pursue arguments concerning value: "If, in my own cultural practice, I prefer Dickens to Barbara Cartland, Meat Loaf to U2, shouldn't I be prepared to argue the case for my values. . . . Shouldn't I be able to persuade [support] them with classroom as well as hallway arguments?" (16). Given the case study investigated here, the answer to Frith's question should perhaps be a hesitant yes, a yes with certain cautions. First, outside of the question of what we enjoy and what we value, we need to take responsibility for our construction of the object of value and for the way in which it gets used culturally, to take responsibility for the meanings we help bring into being through the critical act. As Zizek notes, "For the reality to appear to us as the field of our own activity (or 
inactivity), we must conceive it in advance as 'converted'-we must conceive ourselves as formally responsible-guilty for it" (For 217). In short, as consumers of a text, we need to "know what we do." Our arguments about musical preferences should acknowledge the ideological implications of these preferences. In acknowledging that our arguments about value help in the constitution of culture, we are taking responsibility for what we help create. I am not assuming a passive audience; rather, I am assuming that academic and popular critics do help shape the way in which fans value music and discuss the music they value. Kiss, for example, could be "talked about" by critics in multiple ways, with varying ideological assumptions and effects. However, the Kiss spectacle becomes an ironic celebration of capitalism and sexism (as I have shown above) in part because popular music critics help constitute it as such. And the effects of valuing this creation are the political responsibility of critics.

Second, I want to suggest that we move with Frith to discuss a theory of pain in terms of our musical values, as well as a theory of pleasure. Again, Frith notes early on in Performing Rites that transgressive music, transgressive aesthetics, are necessarily difficult. Frith correctly observes that "The 'difficult' appears through the traces it carries of another world in which it would be 'easy.' The utopian impulse, the negation of everyday life, the aesthetic impulse that Adorno recognized in high art, must be part of low art too" (20). While not all "utopian" worlds are ones we would care to endorse, the "difficult" or "painful" is where our attention must be focused when we are searching for transformative sounds and meanings. In an essay attempting to curtail some of the more celebratory and populist moves in cultural studies, Celeste Condit noted that part of the difficulty faced by those who encounter texts that work against their political interests is that the viewer must use so much energy in fighting the (psychological) pain of these texts that it is often difficult to produce a resistant reading (118-19). In her example, a young man with pro-life politics has difficulty finding ways to "overturn" the meanings embedded in a pro-choice episode of a television series. Condit notes that not only did the young man's "interpretation require more time and space, and visibly more effort (his nonverbal behavior was frequently tense and strained), it showed itself to be more incomplete and problematic in other ways" (108). Hence, faced with a text that implied the "rightness" of an ideology other than his own, the viewer experienced pain, a pain that he would withdraw from after Condit's study by, we expect, never watching the show again. Perhaps one of the things we can learn from this as critics is that there is value in turning toward texts that initially give us pain. If, rather than feeling the 
pain and anxiety caused by the idea of arguing against an oppositional text, the young man had imagined a world in which the text was "easy," his own politics would have been opened for question and reflection. As critics, it is not only a wise idea that we seek out those musical texts which at first give us pain, imagining the possible worlds envisioned within the music, but it seems to me to be part of the critical responsibility. While we obviously do not endorse the "utopias" implied by all texts that we find painful (e.g., it is doubtful that the young man of the example would suddenly endorse a pro-choice position), it seems imperative that we turn toward these painful texts and "painful" interpretations as possibilities rather than always seeking comfort in the easy interpretation (e.g., the celebration of irony in the Kiss discourse).

Only difficult or painful texts/interpretations-what Jacques Attali would refer to as "noise"-can force a critical rethinking of the social imaginary. Only such texts force us to rethink what falls outside the lines, to reevaluate where those lines lie, and to understand the ways common interpretations may be harmful to specific groups and individuals. To listen to what makes me uncomfortable rather than to cynically celebrate that which doesn't, seems to me to have far stronger, far more interesting, political possibilities. For example, Cynthia Fuchs argues that heterosexual audience members at queer punk shows, or "white male" audience members at music shows in which white males are critiqued, often have to invert the pain of their positions during the show by performing as if they were other-as if they were queer, as if they were not white. In this moment of an audience performance in which, "For this night, anyway, everyone here was 'queer," something of a political nature is learned by everyone in the audience (102). If pain comes from walking against the stability of the straight line, then such pain can force critics to think about, and publicly discuss, the possibility of other lines. Again, while some painful texts might lead to ideologies that are politically problematic, other texts that might at first seem painful (e.g., I recall how the first time I heard Ice Cube's voice and lyrics on "Gangsta, Gangsta," I was physically frightened) might have something productive to offer (as indeed, NWA eventually did by forcing me to rethink the material problems faced by specific groups in our culture). By making some note of the aesthetics of pain, and by being far more careful about the discourse of pleasure, critics can publicly value conscious rather than complicitous desires.

As a conclusion, then, Frith notes in the final chapter of Performing Rites: "In examining the aesthetics of popular music, we need to reverse the usual academic argument: the question is not how a piece of music, a text, 'reflects' popular values, but how-in performance-it produces 
them" (270). What I am calling for here in short is that, as critics, we must learn to extend such a claim over our own values; we must give far more attention to the way we talk about and learn those values critically, and the way (and times) we hold accountable popular music critics for helping produce or perform those values. That is, one of our most diligent questions must be, not how a piece of music criticism reflects individual values, but how-in performance-it produces them. While musicians and performers reflect on how their "product" produces values, our focus as critics must be on how our own product-the way we frame interpretation--shapes vahues.

\section{Acknowledgments}

The author would like to thank Steve Jones, Karen Shimakawa, Elliott Vanskike, Andrew Herman, and Thom Swiss.

\section{Notes}

1. While I've run across this quotation several times in the original and in other essays, I was reminded of it in writing this essay when I ran across it in Neil Nehring's Popular Music, Gender, and Postmodernism. Such a comment is by now fairly obvious in both critical and popular media circles. Indeed, it would be hard to deny by looking at a random issue of Entertainment Weekly that "post" theories have, at least in a limited form, had an impact on popular critical writing. One might raise the question of why this "trickle down" in discourse is occurring. It is in many ways a question that I am not able to answer. However, as Steve Jones ("Reading" 203-07) points out, the fact that there is a shared discourse is not a sign that animosity between popular critics and academic critics of popular culture has lessened. In my mind, the "trickle down" effect in popular music criticism is caused by the need for differentiation as various critics try to make themselves appear different from each other. Paralleling Stabile's analysis of how academic critics differentiate themselves from one another through the use of specific theories, I would suggest that a similar move occurs among recently educated popular music critics.

2. I hesitate to even employ the term "postmodern," as the multiplicity of meanings for this term, and the number of theories and theorists grounded under, or excluded from, its heading, seemingly change from day to day and author to author. When I use the term in this essay, I am either employing it as the quoted author did, or I will attempt to provide a strong sense of what I am implying. Early in the article, I am simply trying to illustrate that the question of postmodernity and criticism is a matter of some concern. 
3. While I have a number of issues with Nehring's argument, he is particularly strong in investigating the relationship between academic and popular criticism as regards popular music and postmodernity. For other arguments on this relationship, see Steve Jones's ("Reading") discussion of the implications and effects of the public discussions of the "Madonna studies" books of the early 1990s. As well, many essays in the Steve Redhead-edited Clubcultures Reader would be of interest to those investigating this relationship.

4. For an example of a recent essay dealing with the way "authenticity" as a concept continues to operate in popular music, although changing in meaning from a romantic notion of authenticity to a logic of free appropriation and pastiche, see Andrew Herman and John M. Sloop's study of the Negativland-U2 case.

5. My primary focus will be on the discourse surrounding the rock band Kiss. A comparison/contrast with public discussions of the Sex Pistols will be useful in understanding the changing meaning of such terms as "authenticity" and in understanding the way music criticism approaches to each band reveal general changes.

6. In short, I am taking a "materialist's" look at some aspects of music fanship and criticism, in the sense that McGee uses the term "material." Rather than layering a theoretical meaning for postmodernity over popular culture to see if such a condition indeed exists, I'm more interested in looking to see how music is talked about (i.e., I am assuming that "the music is as the music does" in public discussions about it).

7. In Jensen and Pauly's discussion of audience research, they note that cultural studies rarely provide an autobiographical account of the author's own "personal tastes, sensibilities, and responses" (167). Here, in that spirit and that of recent autoethnographies, I want to briefly share my own experience at a show during the Kiss reunion tour in order to illustrate my own pleasures and to provide evidence of how audience members took enjoyment in the show. In the interest of space, I chose not to provide a similar illustration of the Sex Pistols reunion, but it too fell in line with the dominant critical discussions of the show.

8. Again, by popular music criticism, I am referring here to music criticism in "popular" mass media and not academic journals.

9. I used a number of different data bases to retrieve articles concerning the bands in each period: The Music Index, The New York Times Index, Reader's Guide to Periodical Literature, and ProQuest. While I did not find (and do not cite) every article from each of these sources, I gathered a majority of them and provide readings that match what I see as the overall articulation of each band, as well as concepts articulated with the band, during each era. I feel comfortable that these would be fairly standard readings (i.e., I've not "gone out on a limb" at any point). 
10. More, my observations of the audience at both shows I attended and my discussions with multiple others who attended shows in other areas indicate that a good number of the attendees of the Kiss and Sex Pistols shows were not active fans (i.e., they hadn't continued to follow the bands or band members since the 1970s) and were attending for nostalgia. Hence, audience members are more likely to have been shaped by dominant discourses than by fanzines.

11. I have two comments to make on this point. First, in her study of the ways critics have conceptualized the relationship between mass media and culture, Joli Jensen (85-88) notes that a general narrative is told in which mass media are seen as corrupting, or making inauthentic, "natural culture." Authenticity is rhetorically linked to naturalness, truth, reality, and progress, with mass media being linked to "inauthenticity." In this narrative, the "artist" is articulated as one who brings us closer to "authentic" truth by cutting through mass mediation (115-16). The constructs Jensen describes are certainly similar to those operating in rock culture.

Second, while some would argue that the Sex Pistols were remembered as well for manipulating money out of the recording industry, in their case this was often seen as a political act rather than as one of avarice. Indeed, Greil Marcus links the politics of punk with the Situationists in his Lipstick Traces.

12. It is safe to grant, however, that there were pockets of people (such as my parents) who read Kiss as somewhat dangerous in a Satanic sense.

13. Again, the ideology of "independence" is clear in this claim. A band posited as having "independent" thought is generally articulated along with the notion of an independent rather than a "corporate" record company. These distinctions are empirically difficult to tie down in the phenomenon of independent music labels, given their links with "big" music labels, but the distinction between how labels treat artist autonomy is never as clear as the label the band is signed to. As with other facets of rock authenticity, an independent record label is as much rhetorical as phenomenological. For a discussion of the complex relationship between "The Big 6" (now "The Big 5") record labels and the rest of the industry, see Mark Crispin Miller's "Who Controls the Music?" or David Sanjek's "Popular Music and the Synergy of Corporate Culture."

14. I am quoting here from a reprint of the article published in 1977.

15. Again, while I can point to Herman and Sloop's recent essay as an example of a case in which there was a clear contemporary usage of a concept of authenticity at work in the discourse of fans, critics, and record producers, I would argue that the "authentic inauthenticity" thesis is correct to a dangerous level. The reasons for this move, and its appearance in the rapid ironic repackaging of numerous items from 1970 popular culture (e.g., The Brady Bunch), can be explained through numerous overlapping causal models if one wishes (e.g., simple generational nostalgia, the proliferation of media images in an age of "simulation"), but I don't see that as my task, or as important to my task. 
Given that I am concerned with intervening in a practice that I currently see as dangerous or troubling, I want to work at the level of practice rather than causal speculation.

16. See, e.g., such headlines as "Kiss, Sex Pistols to Join the Reunion Tour Circuit" (Gunderson) and "Tours: From Sex Pistols to KISS, the Summer of . . . "76?" (Wild, "Tours"), which use a discussion of these two bands as representing the strength of nostalgia in the rock tour summer season.

17. Perhaps this is the "other side" of the darker cynicism seen by Steve Jones ("Covering" 115) in the rumors that arose in 1994 after Kurt Cobain's death that Cobain had been murdered by his record company in order to ensure sales of Nirvana's records after the demise of the band. In both cases, the cynicism indicates an acceptance that "industry" music is ultimately about sales.

18. Once again, and I hope this disclaimer doesn't wear too thin, I'm not positing that authenticity as a concept is completely erased in popular cultureas a rhetorical product, I know it is still in use. I am more simply suggesting that there are good reasons for a critical project concerned with its public usage.

19. For a nice restatement of this point in contemporary fiction, one should see David Foster Wallace's Infinite Jest. In one scene, character Hal Incandenza is watching videotapes of films made by his now deceased father. At one point, Hal notes the way his father

had made films in certain commercial-type genre modes that so grotesquely exaggerated the formulaic schticks of the genres that they become metacinematic parodies on the genres, "subinversions of the genres," cognoscenti taken in were wont to call them. The metacinematic-parody idea itself was aloof and overclever, to Hal's way of thinking, and he's not comfortable with the way Himself [Hal's father] always seemed to get seduced by the very commercial formulae he was trying to invert. (703-04)

Such a criticism fits well into the critical reads of Kiss and would certainly be interesting to apply to such films as the Scream series.

20. If one can find "celebratory" configurations of enjoyment now, it is more likely to be in mass-media criticism than in academic cultural theory (where it would have been a decade ago). Again, the concern I have is with mass-mediated criticism and its conceptions of music and pleasure rather than with theoretical and academic ones.

21. Attali makes a distinction between noise and music. He suggests that, in terms of culture, relations of power can be found in the shifting boundary between noise and music. Music is tamed noise: music is a structural code that defines the hegemonic ordering of positions of power and difference located in the aural landscape of sound. Noise, on the other hand, falling outside of dominant codes, transgresses the dominant ordering of difference. Music affirms the dominant order while noise threatens it. We have all had experiences that tell us 
that what was once noise can become music through familiarity, through learning to listen otherwise (i.e., familiarity can make what was once noise sound like music in the same way that once unacceptable behavior becomes acceptable the more often it is repeated). Just as I generally prefer pleasure to pain, I generally prefer music to noise, but if the critical project is going to be involved in change rather than reification, I need to learn to seek out particular forms of noise, ones that could be politically progressive, rather than sit in the comfort of the music of irony. If we allow the comfort of irony to exist without our disruption, we allow ourselves to be free of all blame for "our economic system, our social choices, our actions, and our desires" (Jensen 195).

\section{Works Cited}

Ali, Lorraine. "Devil's Haircut." Rolling Stone 21 Aug. 1997: 44.

Attali, Jacques. Noise: The Political Economy of Music. Minneapolis: $U$ of Minnesota P, 1985.

Bozza, Anthony. "Kiss." Rolling Stone 10 July 1997: 24.

Christgau, Robert. "Forever Rotten." Village Voice 13 Aug. 1996: 47-49.

Condit, Celeste Michelle. "The Rhetorical Limits of Polysemy." Critical Studies in Mass Communication 6 (1989): 103-22.

Dowling, Colette. "An Outrage Called Kiss." New York Times 19 June 1997, sec. 6: 18-19, 66-70.

Frith, Simon. Performing Rites: On the Value of Popular Music. Cambridge, MA: Harvard UP, 1996.

Fuchs, Cynthia. "If I Had a Dick: Queers, Punks, and Alternative Acts." Mapping the Beat: Popular Music and Contemporary Theory. Ed. Thom Swiss, John M. Sloop, and Andrew Herman. Malden, MA: Blackwell, 1997. 101-20.

Goodwin, Andrew. Dancing in the Distraction Factory: Music Television and Popular Culture. Minneapolis: U of Minnesota P, 1992.

__. "Popular Music and Postmodern Theory." Cultural Studies 5 (1990): 174-90.

Grossberg, Lawrence. We Gotta Get Out of This Place: Popular Conservatism and Postmodern Culture. New York: Routledge, 1992.

Gunderson, Edna. "Kiss, Sex Pistols to Join the Reunion Tour Circuit." USA Today 4 Apr. 1996: D8.

Hall, Claude. "Kiss/Cheap Trick: Forum, Los Angeles." Billboard 10 Sept. 1997: 37.

Harrington, Richard. "Sex Pistols: Apathy in the U.S.A." Washington Post 8 Aug. 1996: C2.

Herman, Andrew, and John M. Sloop. "The Politics of Authenticity in Postmodern Rock Culture: The Case of Negativland and the Letter ' $U$ ' and the Numeral '2.'" Critical Studies in Mass Communication 15 (1998): 1-20. 
hooks, bell. "Cool Cynicism: Pulp Fiction." Reel to Real: Race, Sex and Class at the Movies. New York: Routledge, 1996. 47-51.

Jenkins, Mark. "Son of a Gun! The Pistols Are Together Again." Washington Post 4 Aug. 1996: G2.

Jensen, Joli. Redeeming Modernity: Contradictions in Media Criticism. Newbury Park, CA: Sage, 1990.

Jensen, Joli, and John J. Pauly. "Imagining the Audience: Losses and Gains in Cultural Studies." Cultural Studies in Question. Ed. Marjorie Ferguson and Peter Golding. Thousand Oaks, CA: Sage, 1997. 155-69.

Jones, Peter. "Virgin Pacts Pistols; 3d Deal in 6 Months." Billboard 28 May 1997: 68.

Jones, Steve. "Covering Cobain: Narrative Patterns in Journalism and Rock Criticism." Popular Music and Society 19 (1995): 103-18.

- - "Reading Pop: The Press, the Scholar and the Consequences of Popular Cultural Studies." The Clubcultures Reader. Ed. Steve Redhead. Malden, MA: Blackwell, 1997. 204-16.

- "Re-Viewing Rock Writing: Recurring Themes in Popular Music Criticism." American Journalism 9 (1993): 87-107.

LaFranco, Robert. "Retread Rock." Forbes 23 Sept. 1996: 156-58.

Lendt, Christopher K. Kiss and Sell: The Making of a Supergroup. New York: Billboard, 1977.

Marcus, Greil. Lipstick Traces: A Secret History of the Twentieth Century. Cambridge, MA: Harvard UP, 1989.

McGee, Michael.Calvin. "A Materialist's Conception of Rhetoric." Explorations in Rhetoric: Studies in Honor of Douglas Ehninger. Ed. Raymie C. McKerrow. Glenview, IL: Scott, Foresman, 1982. 23-48.

Milano, Brett. "Kiss: Unplugged." Stereo Review June 1996: 82.

Miller, Mark Crispin. "Who Controls the Music?" The Nation 25 Aug. 1997: 11-16.

Negus, Keith. Popular Music in Theory. Hanover, NH: Wesleyan UP, 1996.

Nehring, Neil. Popular Music, Gender, and Postmodernism: Anger Is an Energy. Thousand Oaks, CA: Sage, 1997.

Nusser, Dick. "Kiss/Sammy Hagar: New York." Billboard 5 Mar. 1997: 89.

“Poll Reveals Kiss Teeners' Favorite." Billboard 16 July 1977: 89.

Redhead, Steve, ed. The Clubcultures Reader. Malden, MA: Blackwell, 1997.

Reed, Roy. "Punk Rock, Britain's Latest Fad, Leaves Trail of Violence in Wake." New York Times 11 July 1977: 2.

Robbins, Jeff. "Letters." New York Times 10 July 1977, sec. 6: 46.

Rockwell, John. "Kiss Satisfies Need for Glitter at Rock Show." New York Times 20 Feb. 1977, sec. 6: 12.

—. "The Sex Pistols: A Fired-Up Rock Band." New York Times 17 Aug. 1977: $16,68-70$. 
-. "Sex Pistols are Given Visas to Enter U.S. for Concerts." New York Times 31 Dec. 1977, sec. 6: 4.

Sanjek, David. "Popular Music and the Synergy of Corporate Culture." Mapping the Beat: Popular Music and Contemporary Theory. Ed. Thom Swiss, John M. Sloop, and Andrew Herman. Malden, MA: Blackwell, 1977. 171-86.

Sinclair, David. "Performance: The Sex Pistols." Rolling Stone 8 Aug. 1996: 30.

Smith, R. J. "It's Alive." Spin Aug. 1996: 44-52, 112.

Stabile, Carol A. "Resistance, Recuperation, and Reflexivity: The Limits of a Paradigm." Critical Studies in Mass Communication 12 (1995): 403-22.

Wallace, David Foster. Infinite Jest. Boston: Little, Brown, 1996.

White, Chris. "A\&M Draws Sex Pistols; Sees Act as 'New Force.'" Billboard 26 Mar. 1977: 70.

Wild, David. "Performance: Kiss." Rolling Stone 8 Aug. 1996: 32.

—. "Tours: From Sex Pistols to Kiss, the Summer of . . . '76?" Rolling Stone 13 June 1996: 52-53.

Young, Charles M. "Rock Is Sick and Living in London." 20 Years of Rolling Stone: What a Long, Strange Trip It's Been. Ed. Jann S. Wenner. New York: Friendly P, 1987. 306-18.

Zizek, Slavoj. For They Know Not What They Do. New York: Verso, 1991.

—. The Sublime Object of Ideology. New York: Verso, 1989.

John M. Sloop is Assistant Professor of Communication Studies at Vanderbilt University in Nashville, Tennessee. 